\title{
Original Article \\ Assessment of relation between otitis media and wheezy chest in pediatric
}

\section{Pediatrics}

Sara L. Mostafa ${ }^{1}$, Esaad M. Menazie ${ }^{1}$, Asmaa A. Ibrahim ${ }^{1}$, Fatma M. Elhussieny ${ }^{2}$

${ }^{1}$ Pediatrics Department, Faculty of Medicine for Girls, Cairo, Al-Azhar University, Egypt.

${ }^{2}$ Otorhinolaryngology Department, Faculty of Medicine for Girls, Cairo, Al-Azhar University, Egypt.

\section{ABSTRACT}

Background: In children, wheezing is a common symptom that needs medical consultations, emergency care services, and hospitalization. The middle ear may behave in a "similar manner to the lungs under allergic inflammatory insults" and that the middle ear may be included in the united airways.

Objective: To detect the association between the wheezy chest and the presence of otitis media (OM).

Methodology: This study included 100 children with a wheezy chest, 54 male and 46 females; all cases were subjected to entire history taking, clinical examination, complete blood count $(\mathrm{CBC})$ and $\mathrm{C}$ - reactive protein $(\mathrm{CRP})$ analysis, otoscopic examination, tympanometry, audiometry, additionally auditory brain stem response (ABR) in noncooperative children.

Results: In the current study, 47 cases $(47 \%)$ had bronchial asthma, and 53 cases $(53 \%)$ had pneumonia. Among the studied cases, $43 \%$ had OM (61\% suffering from bronchial asthma and $26.4 \%$ suffering from pneumonia). Among the 43 cases of OM, 39 cases $(90.6 \%)$ were complicated by conductive hearing loss (CHL), while 4 cases (9.3\%) were complicated by sensory neural hearing loss (SNHL). Anemia has a strong correlation with OM.

Conclusion: there is an association between wheezy chest, whether caused by bronchial asthma or pneumonia, and OM development.

JRAM 2021; 2(2): 204-213

Keywords: Children, wheezy chest, otitis media, conductive hearing loss.

Submit Date: 23 April 2021

Acceptance Date: 30 May 2021

Corresponding author: Sara Lotfy Mostafa, pediatric department, faculty of medicine for girls, Cairo, Al-Azhar university, Egypt. Tel: 01021851880. E-mail: Saralotfymf@gmail.com.

Please cite this article as: Sara L. Mostafa ${ }^{1}$, Esaad M. Menazie ${ }^{1}$, Asmaa A. Ibrahim ${ }^{1}$, Fatma M. Elhussieny. Assessment of the relation between otitis media and wheezy chest in pediatric. JRAM 2021; 2(2): 204-213. DOI: 10.21608/jram.2021.73164.1114

\section{INTRODUCTION}

In children, wheezing is a common symptom that needs medical consultations, emergency care services, and hospitalization ${ }^{[1]}$. Childhood asthma is triggered and exacerbated by respiratory viral infections. The early childhood viral infections which infect the lower airways can be associated with chronic lower respiratory tract symptoms, including asthma ${ }^{[2]}$. Otitis media can be subdivided into acute otitis media (acute suppurative, non-suppurative, and recurrent acute otitis media) and chronic otitis media (chronic suppurative, non-suppurative with effusion, and non-suppurative without effusion) ${ }^{[3]}$.

After viral upper respiratory tract infection, inflammation in the nose, nasopharynx, eustachian tubes, and middle ear mucosa leads to OM development. This inflammation leads to edema that obstructs the eustachian tube; this, in turn, causes a decrease in ventilation and a cascade of events that finally increased the middle ear's negative pressure and increased exudate from the inflamed mucosa. Inflamed mucosa organisms lead to suppuration in the middle ear ${ }^{[4]}$. The middle ear is ventilated 3 to 4 times $/ \mathrm{min}$. The affection of middle ear patency develops negative pressure that leads to accumulation of fluid which causes hearing loss. Eustachian tube dysfunction may be secondary to allergies, inflammation in the nasopharynx, or benign or malignant tumors ${ }^{[5]}$.

Asthma patients have inflammation of the lower airway due to Th1 and Th2 immune responses. This inflammation may induce the inflammation of the mucosal orifice of the eustachian tube and impeding the ventilation of the middle ear ${ }^{[6]}$. Recurrent wheezing and airway secretions could physically obstruct the eustachian tube. This obstruction affects the mucociliary clearance and promotes the accumulation of infection and OM development ${ }^{[6]}$. This work aimed to find an association between a wheezy chest and the presence of OM. 
The study rationale: It is essential to do an audiological study (tympanogram and audiometry alternatively auditory brain stem response (ABR) in every child with wheezy chest to assess the presence of otitis media.

\section{SUBJECTS AND METHODS}

This observational, descriptive cross-sectional study was carried out on 100 children selected from the pediatric department in Al-Zahraa University Hospital, Cairo, Egypt, from November 2019 to May 2020. Their age ranges from two to ten years old. They were 54 male, 46 females. Chest auscultation was revealed that all selected children had expiratory rhonchi. Children-are known to have congenital hearing loss, congenital anomalies of the chest, or congenital anomalies of the ear. Also, we excluded children with a history of taking any ototoxic drugs.

All the studied cases were subjected to history taking, complete systemic examination, including the respiratory system. Investigations in CRP and complete blood count analysis by Sysmex Xp300, Egypt, and Chest X-ray-were done for all studied children. Audiological examination in the form of an otoscopic examination, tympanometry, audiometry was done for all children, while auditory brain stem response was made only for non-cooperative children (Eclipse Ep 25 intercostal machine, Denmark).
Bronchial asthma was diagnosed according to GINA (2020). Pneumonia was diagnosed based on clinical and radiological findings ${ }^{[7]}$. Suppurative otitis media (SOM) was diagnosed by the presence of congestion, hyperaemic, and bulging tympanic membrane by otoscope and tympanometry showing type B OM. Disturbed cone of light and retracted tympanic membrane (DCL and RTM) diagnosed by otoscope showing dull and retracted tympanic membrane and tympanometry showing type B OM. Anemia in our cases diagnosed based on hemoglobin level $(\mathrm{Hb})$, hematocrit \%(Hct\%), and mean corpuscular volume (MCV) according to nelson guidelines ${ }^{[8]}$. The study was approved by the institutional review board of faculty of medicine for girls, Cairo, Al-Azhar University, Egypt, (IRP number was201911244). Informed written consent was taken from the parents of the studied children.

Statistical analysis Statistical analysis was performed using SPSS version 25. for Windows \& MedCalc v. 20 The difference in the means of continuous variables was analyzed using the independent sample $\mathrm{T}$. test. The quantitative variables were in the form of mean \pm standard deviation (SD), minimum and maximum. Description of qualitative variables was in the form of numbers (n) and percent (\%). Comparison between qualitative variables was carried out by Chi-squared test. The results were significant when $\mathrm{p}$-value $\leq 0.05$ (CI 95\%)

a)

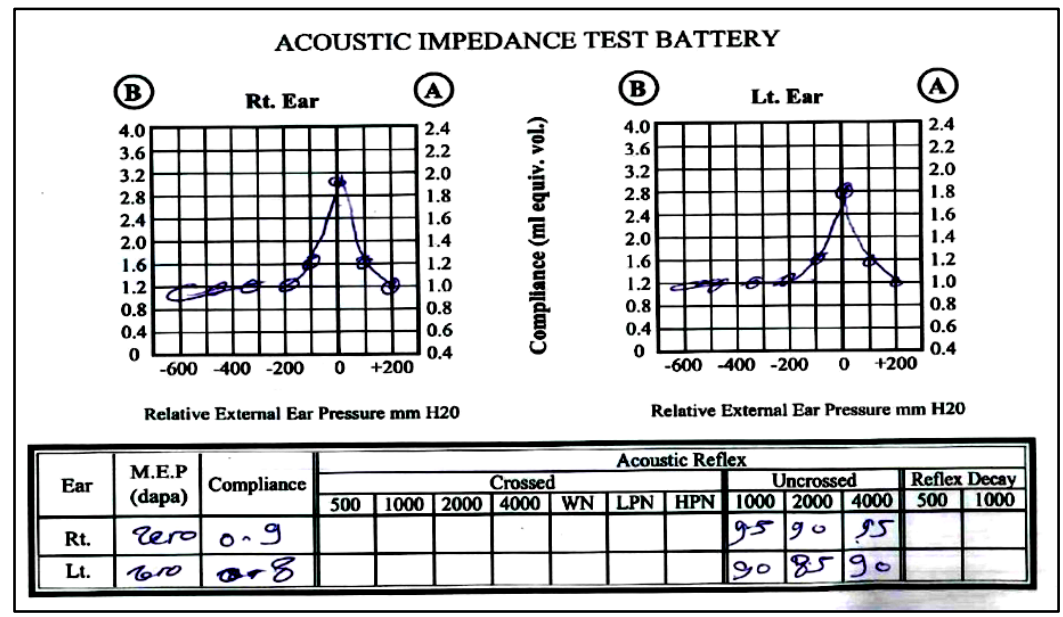

b)

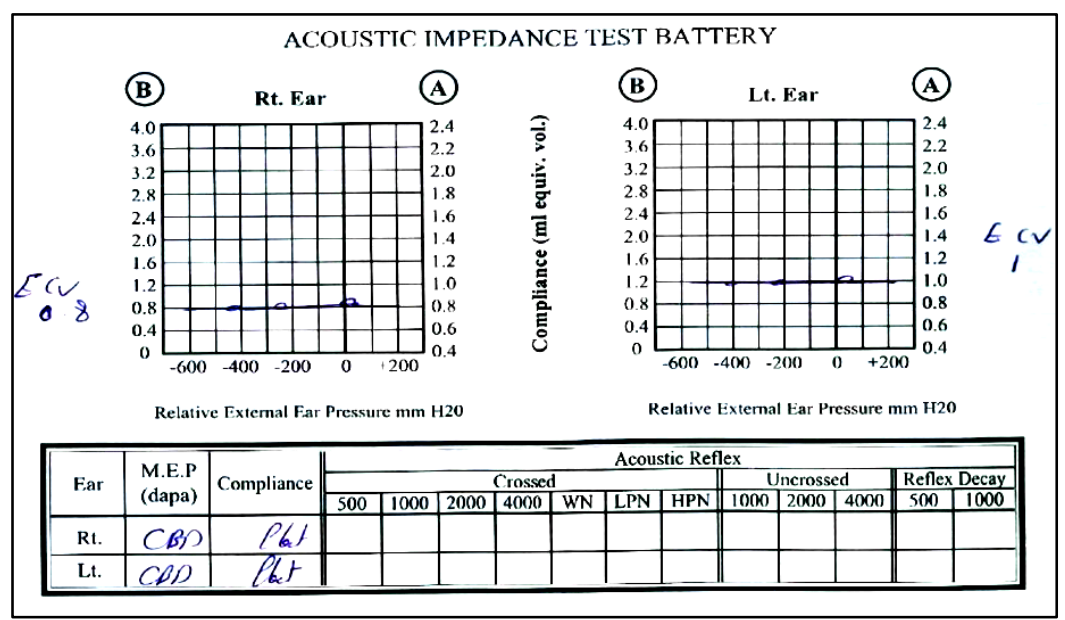


c)

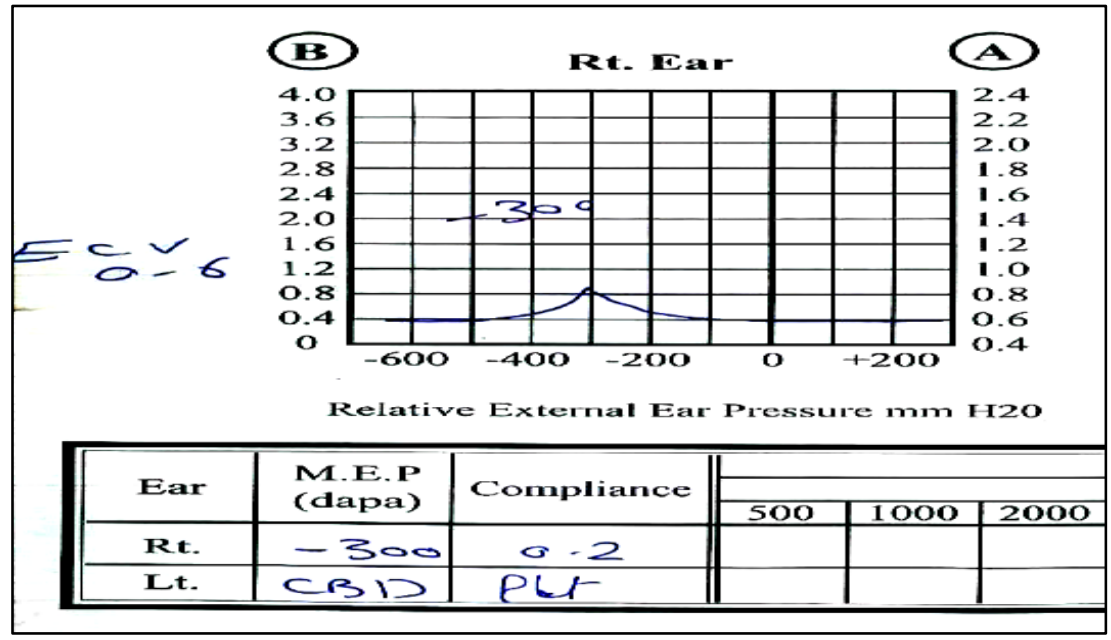

Figure (1): Tympanogram of one of our cases has bronchial asthma, a) showing bilateral type A tympanogram (standard), b) Tympanogram of one of our cases has pneumonia and leading bilateral type B tympanogram, c) Tympanogram of one of our cases has bronchial asthma and showing right ear type $\mathrm{C}$ tympanogram.

a)

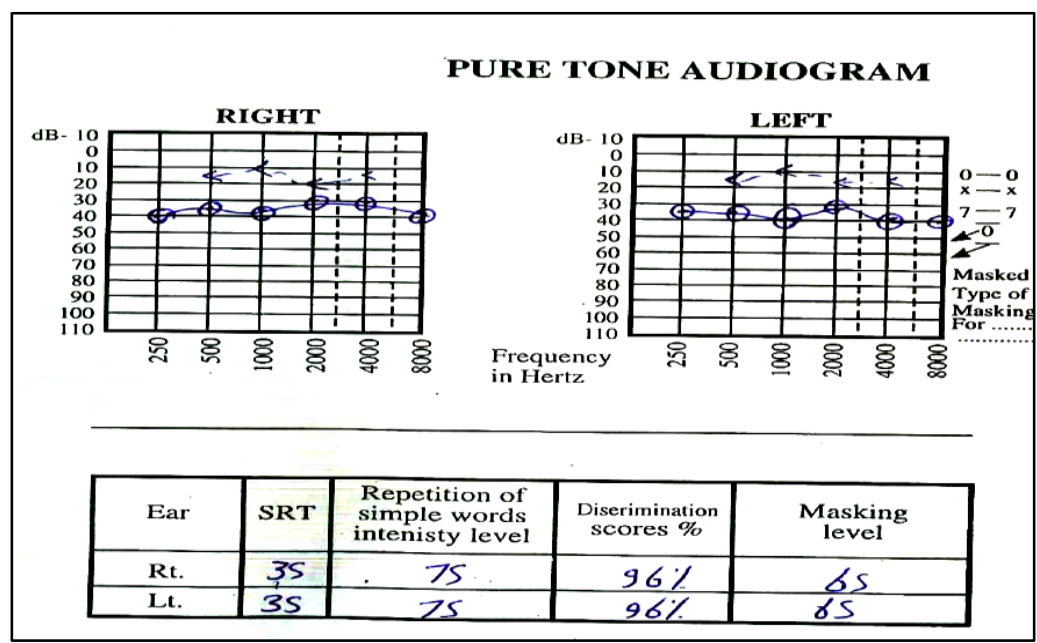

b)

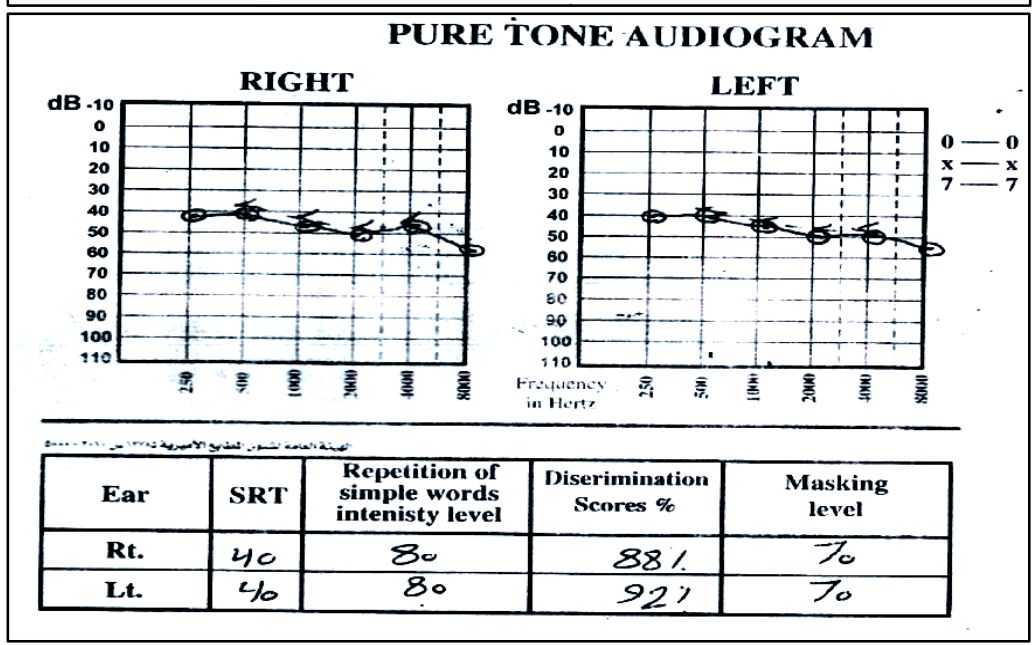


c)

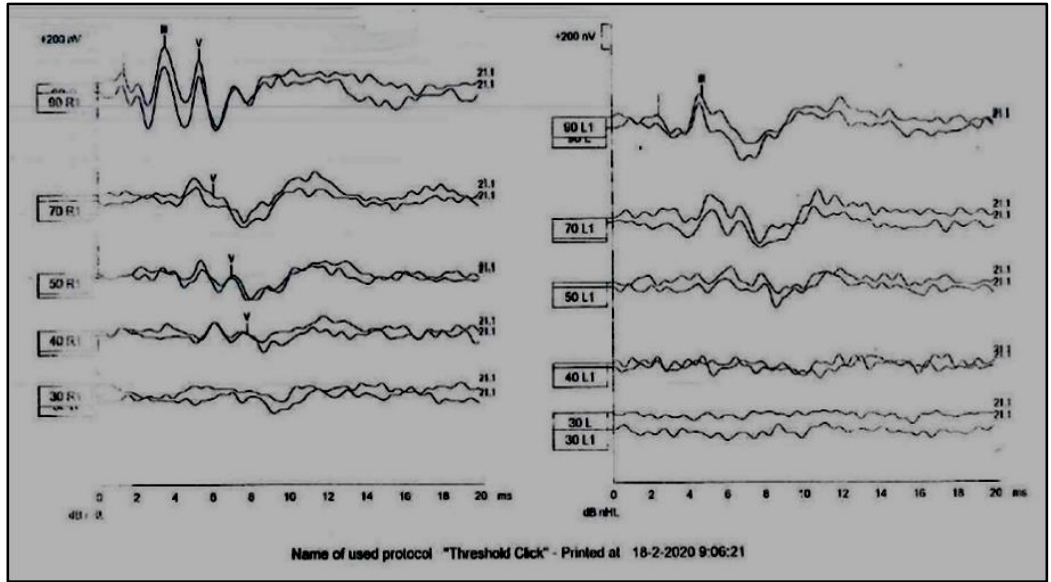

Figure (2): a) Audiometry of one of our cases has bronchial asthma. It shows a bilateral conductive hearing loss, b) Audiometry of one of our cases has bronchial asthma and shows a bilateral sensory neural hearing loss, c) ABR of one of our cases has pneumonia and showing Bilateral identified. Repeatable ABR waves (1\&3\&5), wave 5 traced down to 40 dbnhl in RT ear and down to $50 \mathrm{dbnhl}$ in LT ear representing bilateral mild conductive hearing loss most probably due to conductive element (type B tympanogram).

\section{RESULTS}

Table (1): General characters of the studied cases

\begin{tabular}{|c|c|}
\hline Sex & n $(\%)$ \\
\hline Male & $54(54 \%)$ \\
\hline Female & $46(46 \%)$ \\
\hline Anthropometric data & Mean \pm SD (Range) \\
\hline Weight Z score & $0.00 \pm 1.00(-1.5-3.1)$ \\
\hline Height $\mathrm{Z}$ score & $0.00 \pm 1.00(-2.1-2.2)$ \\
\hline BMI Z score & $-0.00 \pm 1.00(-2.2-2.9)$ \\
\hline \multicolumn{2}{|l|}{ Vital signs } \\
\hline Heart rate (Median, IQR) & $120(20.5)$ \\
\hline Respiratory rate (Median, IQR) & $29(14.5)$ \\
\hline Temperature (Mean \pm SD (Range) & $37.43 \pm 0.67(37-39)$ \\
\hline Systolic blood pressure (Mean \pm SD (Range) & $102.99 \pm 9.64(85-120)$ \\
\hline Diastolic blood pressure (Mean \pm SD (Range) & $65.94 \pm 6.78(50-80)$ \\
\hline Laboratory results & Mean \pm SD (Range) \\
\hline WBCs (x109 cells/L) & $11.63 \pm 5.11(3.90-25)$ \\
\hline RBCs (x1012 cells/L) & $4.24 \pm 0.61(3-5.40)$ \\
\hline $\mathrm{Hb}(\mathrm{g} / \mathrm{dl})$ & $10.77 \pm 1.05(7.30-12.90)$ \\
\hline Hct $\%$ & $35.52 \pm 2.67(30-40)$ \\
\hline MCV (femtoliter) & $75.88 \pm 2.67(70-79)$ \\
\hline Platelets $(109 / \mathrm{L})$ & $389.6 \pm 125.2(159-665)$ \\
\hline Eosinophil \% & $0.76 \pm 0.68(0.10-2)$ \\
\hline CRP (mg/L) & $22.12 \pm 19.09(6-96)$ \\
\hline Otitis media & n $(\%)$ \\
\hline Total & $43(100 \%)$ \\
\hline With bronchial asthma & $29(67.5 \%)$ \\
\hline With chest infection & $14(32.5 \%)$ \\
\hline
\end{tabular}

Table (1) demonstrates general characters of the studied cases. Table (2) revealed that 29 patients $(61.7 \%)$ out of 47 patients with bronchial asthma had DCL and RTM, while 14 patients $(26.4 \%)$ out of 53 patients with pneumonia had SOM. Table (3) revealed that 43 patients $(43 \%)$ out of the total studied children were diagnosed as
OM; they subclassified into 39 cases $(90.6 \%)$ had conductive hearing loss (CHL), and 4 cases $(9.3 \%)$ had sensory neural hearing loss (SNHL). Table (4) revealed that there was a significant increase of leucocytic count and CRP in cases with suppurative OM in comparison to cases with a disturbed cone of light (DCL) and retracted 
tympanic membrane (RTM), with significantly low hemoglobin level in cases of OM as $95.3 \%$ of patient had OM had anemia. Table (5) revealed a statistically significantly higher incidence of OM in males $(65.12 \%)$ than females $(34.88 \%)$. Additionally, there was a statistically significant higher means of vital signs in SOM cases compared to cases with the (DCL and RTM). Table (6) revealed that only eosinophil \% was significant in cases with a wheezy chest with otitis media compared to cases without OM.

Table (2): Distribution of otitis media cases in patients with either bronchial asthma or pneumonia

\begin{tabular}{|l|c|c|}
\hline \multicolumn{1}{|c|}{ Studied groups. } & \multicolumn{2}{|c|}{ Wheezy chest $(\mathbf{n = 1 0 0})$} \\
\hline Types of OM & Bronchial asthma $(\mathbf{n = 4 7})$ & Pneumonia $(\mathbf{n = 5 3})$ \\
\hline DCL and RTM & $\mathrm{n}(\%)$ & $\mathrm{n}(\%)$ \\
\hline SOM & $29(61.7 \%)$ & $0(0 \%)$ \\
\hline
\end{tabular}

DCL and RTM: disturbed cone of light and retracted tympanic membrane, SOM: suppurative otitis media.

Table (3): Otoscopic, tympanogram, audiometry, and auditory brain stem response findings in the studied cases

\begin{tabular}{|l|r|}
\hline Otoscope findings & $\mathbf{n}(\mathbf{\%})$ \\
\hline Normal & $57(57)$ \\
\hline DCL \&RTM & $29(29)$ \\
\hline SOM & $14(14)$ \\
\hline Total & $100(100)$ \\
\hline Tympanogram & \\
\hline Type A (normal) & $57(57)$ \\
\hline Type B & $34(34)$ \\
\hline Type C & $9(9)$ \\
\hline Total & $100(100)$ \\
\hline Hearing loss & \\
\hline Normal hearing & $57(57)$ \\
\hline Conductive hearing loss (CHL) & $39(39)$ \\
\hline Sensorineural hearing loss (SNHL) & $4(4)$ \\
\hline Total & $\mathbf{1 0 0}(\mathbf{1 0 0})$ \\
\hline
\end{tabular}

Table (4): Comparison of CBC, CRP and hemoglobin level according to otoscopic findings

\begin{tabular}{|l|c|c|c|}
\hline \multirow{2}{*}{ Laboratory items } & \multicolumn{3}{|c|}{ Otoscopy } \\
\hline CBC \& CRP & DCL and RTM (n=29) & SOM (n=14) & p value \\
\hline WBCs (x10 ${ }^{9}$ cells/L) & Mean \pm SD & Mean \pm SD & \\
\hline RBCs (x10 12 cells/L) & $9.45 \pm 3.66$ & $16.35 \pm 5.54$ & $0.001^{*}$ \\
\hline Hb (g/dl) & $4.37 \pm 0.63$ & $4.20 \pm 0.64$ & 0.421 \\
\hline Hct \% & $11.07 \pm 1.19$ & $10.83 \pm 0.93$ & 0.137 \\
\hline MCV (femtoliter) & $33.03 \pm 2.40$ & $32.42 \pm 1.50$ & 0.089 \\
\hline Platelets (10 /L) & $73.72 \pm 2.28$ & $72.35 \pm 1.73$ & 0.131 \\
\hline Eosinophil \% & $377.55 \pm 124.33$ & $402.85 \pm 121.78$ & 0.799 \\
\hline CRP (mg/L) (median, IQR) & $0.43 \pm 0.60$ & $0.22 \pm 0.097$ & 0.2031 \\
\hline Otitis media (n= 43) & $6(6)$ & $48(24)$ & $0.001 *$ \\
\hline Anemia & & & \\
\hline Positive [n (\%)] & & & \\
\hline Negative [n (\%)] & $41(95.3)$ & $X^{2}=11,4$ & $0.001 *$ \\
\hline
\end{tabular}


Table (5): Comparison of vital signs and gender according to otoscopic findings

\begin{tabular}{|c|c|c|c|}
\hline \multirow{2}{*}{ Clinical data } & \multicolumn{2}{|c|}{ Otoscopy } & \multirow{3}{*}{ p value } \\
\hline & DCL and RTM & SOM & \\
\hline Vital signs & Mean \pm SD & Mean \pm SD & \\
\hline Heart rate $(\mathrm{b} / \mathrm{m})$ & $111.10 \pm 12.23$ & $130.36 \pm 12.79$ & $0.001 *$ \\
\hline Respiratory rate (c/m) & $25.10 \pm 5.69$ & $39.79 \pm 10.10$ & $0.005^{*}$ \\
\hline Temperature $\left({ }^{\circ} \mathrm{C}\right)$ & $37.17 \pm 0.45$ & $38.06 \pm 0.75$ & $0.001 *$ \\
\hline Systolic pressure (mmHg) & $102.72 \pm 4.73$ & $107.50 \pm 7.84$ & $0.0169 *$ \\
\hline Diastolic pressure $(\mathrm{mmHg})$ & $64.29 \pm 7.30$ & $70.93 \pm 6.61$ & $0.0048 *$ \\
\hline \multicolumn{4}{|l|}{ Otitis media } \\
\hline Sex & \multicolumn{2}{|c|}{ n $(\%)$} & \multirow{3}{*}{$0.0474 *$} \\
\hline Male & \multicolumn{2}{|c|}{$28(65.12)$} & \\
\hline Female & \multicolumn{2}{|c|}{$15(34.88)$} & \\
\hline
\end{tabular}

Table (6): Comparison of studied variables between wheezy chest cases with and without OM

\begin{tabular}{|c|c|c|c|}
\hline \multirow{2}{*}{ Parameter } & \multicolumn{2}{|c|}{ Wheezy chest } & \multirow{2}{*}{$\mathrm{p}$ value } \\
\hline & Without OM $(n=57)$ & OM (n=43) & \\
\hline \multicolumn{4}{|l|}{ Age and sex } \\
\hline Age (Mean \pm SD) & $5.23 \pm 2.23$ & $5.73 \pm 2.40$ & 0.306 \\
\hline \multicolumn{4}{|l|}{$\operatorname{Sex} n(\%)$} \\
\hline Male & $29(50.9 \% \%)$ & $28(65.12)$ & 0.4767 \\
\hline Female & $28(49.1 \%)$ & $15(34.88)$ & 0.4645 \\
\hline \multicolumn{4}{|l|}{ Anthropometric data (Mean \pm SD) } \\
\hline Weight Z score & $-0.17 \pm 0.96$ & $0.23 \pm 1.01$ & 0.053 \\
\hline Height $\mathrm{Z}$ score & $-0.18 \pm 0.96$ & $0.20 \pm 1.01$ & 0.074 \\
\hline BMI Z score & $0.017 \pm 0.97$ & $-0.02 \pm 1.05$ & 0.844 \\
\hline \multicolumn{4}{|l|}{ Vital signs (Mean \pm SD) } \\
\hline Heart rate $(\mathrm{b} / \mathrm{m})$ & $121.73 \pm 15.64$ & $118.65 \pm 15.37$ & 0.352 \\
\hline Respiratory rate (c/m) & $33.14 \pm 17.60$ & $30.76 \pm 10.63$ & 0.474 \\
\hline Temperature $\left({ }^{\circ} \mathrm{C}\right)$ & $37.43 \pm 0.66$ & $37.46 \pm 0.70$ & 0.825 \\
\hline Systolic blood pressure (mmHg) & $102.53 \pm 9.65$ & $103.88 \pm 9.82$ & 0.514 \\
\hline Diastolic blood pressure (mmHg) & $65.84 \pm 6.84$ & $66.18 \pm 6.85$ & 0.819 \\
\hline \multicolumn{4}{|l|}{ Laboratory results (Mean \pm SD) } \\
\hline WBCs $\left(\times 10^{9}\right.$ cells/L) & $11.76 \pm 4.80$ & $11.80 \pm 5.57$ & 0.969 \\
\hline RBCs $\left(\times 10^{12}\right.$ cells/L) & $4.16 \pm 0.61$ & $4.38 \pm 0.60$ & 0.091 \\
\hline $\mathrm{Hb}(\mathrm{g} / \mathrm{dl})$ & $10.65 \pm 1.03$ & $10.95 \pm 1.10$ & 0.188 \\
\hline $\mathrm{HCT} \%$ & $34.09 \pm 1.73$ & $33.44 \pm 2.25$ & 0.093 \\
\hline MCV (femtoliter) & $74.33 \pm 1.83$ & $73.95 \pm 2.38$ & 0.182 \\
\hline Platelets $\left(10^{9} / \mathrm{L}\right)$ & $394.72 \pm 131.57$ & $378.06 \pm 112.43$ & 0.533 \\
\hline Eosinophil \% & $0.55 \pm 0.54$ & $1.04 \pm 0.76$ & $0.001 *$ \\
\hline CRP (mg/L) (median, IQR) & $12(18)$ & $16(22)$ & 0.307 \\
\hline \multicolumn{4}{|l|}{ Anemia [n (\%)] } \\
\hline Yes & $54(94.7 \%)$ & $41(95.3 \%)$ & 0.8926 \\
\hline No & $3(5.3 \%)$ & $2(4.7 \%)$ & 0.8926 \\
\hline \multicolumn{4}{|l|}{ Causes } \\
\hline Bronchial asthma & $18(31.6 \%)$ & $29(67.4 \%)$ & \multirow{2}{*}{$0.041^{*}$} \\
\hline Pneumonia & $39(68.4 \%)$ & $14(32.6 \%)$ & \\
\hline
\end{tabular}




\section{DISCUSSION}

The eustachian tube connects the middle ear cavity with the nasopharynx, so the eustachian tube considers an extension of the upper respiratory tract. So, one airway is one disease because bronchial provocation in the lower airway affects allergic rhinitis in the upper airway, while nasal provocation affects asthma in the lower airway ${ }^{[9]}$.

The middle ear response to allergic and inflammatory insults in a similar manner to the lungs ${ }^{[10+}$. Streptococcus pneumonia colonizes the nasopharynx, sense threatening changes in the nasopharynx resulting from viral infection by upregulating specific sets of genes involved in releasing biofilm, dissemination from the nasopharynx to other sites, become protected against the host immune system ${ }^{[11]}$.

In the present study, among the studied cases, $43 \%$ have OM $(67.4 \%$ suffering from bronchial asthma and $32.6 \%$ suffering from pneumonia) with significant difference between them. Much literature revealed that solid association was present between upper and lower respiratory tract infections. Also, there was a strong association present between bronchial asthma and OM. Wright et al. ${ }^{[12]}$ and El-Sharnoby et al. ${ }^{[13]}$ were found that there was increased expression of allergyassociated inflammatory cells (CD3) and cytokines on the middle ear mucosal specimens from atopic patients compared to control. So, there is a relationship between allergy and inflammation in the middle ear. Igde and Erkilet ${ }^{[14]}$ reported that the mucosa of the middle ear could respond to antigen in the same manner as does the lower respiratory tract mucosa because the mucosa and effusion from atopic patients with $\mathrm{OM}$ with effusion reveal cellular profiles and Th2 cytokine consistent with an allergic response, revealing the allergy role in otitis media with effusion. Shishegar and Ashraf ${ }^{[15]}$ and Sharma et al. ${ }^{[16]}$ reported that upper respiratory tract infections are among the most common causes of eustachian tube dysfunction and thus OM with effusion Hurst ${ }^{[17]}$ Found that among (97\%) patients with otitis media with effusion, (62\%) had documentation of additional atopic signs (whatever skin atopy or bronchial asthma), and bronchial asthma was diagnosed in $22 \%$ of the studied cases. As explained by middle ear mucosa of atopic patients, all components respond to allergic stimulation as respiratory system as TH2, inflammatory response, IL-5, and specific IgE are present in most ear of the atopic patient. Chants et al. ${ }^{[18]}$ also were found that increased the incidence of OM with effusion among atopic children up to five-fold than non-atopic ones. The increasing frequency of respiratory viral infection is explained, which is the primary trigger of acute asthma exacerbation. Interaction between viral infection and allergy increases the risk of middle ear effusion and immunological reaction unrelated to mechanical obstruction only. However, the middle ear is the target organ for allergic reactions, so the reaction to external stimuli affects the middle ear. Chonmaitree et al. ${ }^{[19]}$ were found that respiratory viral and bacterial infections are considered a risk factor for developing acute otitis media.
The eustachian tube dysfunction in our cases may cause by proceeding upper respiratory tract infection, the inflammatory process in the nasopharynx, allergies (in asthmatic cases); all these processes can cause eustachian tube dysfunction. In the present study, among the cases who developed OM, (39) cases have conductive hearing loss (CHL), and four cases have (SNHL). Costa et al. ${ }^{[20]}$ were revealed that hearing loss in $\mathrm{OM}$ is usually conductive, resulting from tympanic membrane rupture or changes in the ossicular chain due to erosion or fixation caused by the chronic inflammation, and they reported that the cause of sensorineural hearing loss in OM is due to the passage of toxins through the membrane of the round window causing permanent loss of hair cell. Costa acts on Six hundred and fifty patients of Chronic Otitis Media and determined bone-conduction thresholds of the affected and normal ear or frequencies 500, 1,000, 2,000, 3,000, and 4,000 $\mathrm{Hz}$. Moreover, found a statistically significant difference between the average bone-conduction thresholds of ears with COM and their controls for all frequencies.

In the present study, leucocytic count and CRP show marked elevation in SOM cases than cases of DCL\&RTM. Peltola et al. ${ }^{[21]}$, Tejani et al. ${ }^{[22]}$, and Nofal and $\mathrm{Al} \mathrm{Kwatly}{ }^{[23]}$ found that elevated CRP level among children with suppurative otitis media than other with only having disturbed the cone of light and retracted the tympanic membrane. Also, Schwartz et al. ${ }^{[24]}$ and Polachek et al. ${ }^{[25]}$ revealed that leucocytic count elevated in acute otitis media.

Among our studied cases who develop otitis media, anemia is a constant risk factor for the development of $\mathrm{OM}$, as $95.3 \%$ of them had anemia Wintergerst et al. ${ }^{[26]}$ concluded that decreased neutrophil and macrophage function and decreased production of pro-inflammatory cytokines are more in anemic children than non-anemic one.

In our study, there is a statistically significant higher mean of vital signs in suppurative otitis media cases compared to typical cases and cases with DCL\&RTM. In agreement with, Salah et al. ${ }^{[27]}$ revealed that vital signs could be used to differentiate children with non-serious bacterial infections from those with serious bacterial infections.

In the present study, out of 43 cases who developed otitis media, (28) males were male compared to (15) females. Association of gender to $\mathrm{OM}$ was studied by Teele et al. ${ }^{[27]}$, Pukander et al. [29], and Matsuoka $\left.{ }^{[30}\right]$, who explained this finding by the association of lower IgG2 among the male of their included cases rather than females. While our cases all are immune-competent, depends on history, clinical and laboratory findings.

There is an increase in eosinophil in OM patients in the present study compared to patients without OM. This agreement with Ohta et al. ${ }^{[31]}$ reported that the number 
of blood eosinophils and the level of IgE increase in otitis media.

This study has a limited number of patients, so studies with a larger sample size would confirm our finding regarding the association between the wheezy chest and otitis media.

\section{CONCLUSION}

In the present study there was an association between the wheezy chest caused by either fbronchial asthma and bronchopneumonia) and OM.

Financial support: no fund was received for this work. Conflict of interest: authors declare any conflict of interest.

\section{REFERENCES}

1. Bessa OA, Leite ÁJM, Solé D \& Mallol J. Prevalence and risk factors associated with wheezing in the first year of life. Jornal de Pediatria (Versão em Português) 2014; 90(2): 190-196.

2. Gern JE. Viral Respiratory Infection and the Link to Asthma. The Pediatric Infectious Disease Journal 2008; 27(10): 97-103.

3. Harkness, P. \& Topham, J. Classification of otitis media. The Laryngoscope 1998; 108: (10): 15391543.

4. Danishyar A and Ashurst JV.2021. Acute Otitis Media. Online at NCBI (The National Center for Biotechnology Information). https://www.ncbi.nlm.nih.gov/books/NBK470332/. Last accessed in May 2021.

5. Miyamoto, R. T. 2015. Middle Ear and Tympanic Membrane Disorders Otitis Media (Secretory). Online at MSD MANUAL

6. Seo Y, Nonaka M, Tagaya E, Tamaoki J, and Yoshihara T. Eosinophilic otitis media is associated with asthma severity and smoking history. J Otorhino-laryngol Relat Special 2015;77(1):1-9.

7. Zar HJ, Andronikou S, Nicol MP. Advances in the diagnosis of pneumonia in children. The bmj (the British Medical Journal) 2017;27(39): 2-10.

8. 8.Kliegman RM and Geme J ST. Nelson textbook of pediatrics (Edition 21.). philadelphia, PA:Elsevier 2020;474:9853.

9. Seo Y, Nonaka M, Yamamura Y, Pawankar $\mathbf{R}$ and Tagaya E. Optimal control of asthma improved eosinophilic otitis media. Asia Pacific Allergy 2018; 8(1).

10. Pazdro-Zastawny K, Zatoński T, OrendorzFrączkowska K, Dorobisz $K$ and MorawskaKochman M. Factors influencing the development of otitis media with effusion in children. Pediatria Polska-Polish Journal of Paediatrics 2019; 94(1): 34-38.

11. Bergenfelz $\mathbf{C}$ and Hakansson AP. Streptococcus pneumoniae Otitis Media Pathogenesis and How It Informs Our Understanding of Vaccine Strategies. Curr Otorhinolaryngol Rep 2017; 5:115-124.
12. Wright AL, Holberg CJ, Taussig LM \& Martinez F. Maternal asthma status alters relation of infant feeding to asthma in childhood. Adv Exp Med Biol 2000; 478: 131-7.

13. 1El-Sharnoby MKM, Ali AAAE, Omar HAH, Habib MSE and Salama HAH. Study of the role of allergy diagnosed by immunoglobulin $\mathrm{E}$ in the etiology of pediatric otitis media with effusion. Menoufia Medical Journal 2017; 30(1): 151.

14. Igde $\mathbf{M} \&$ Erkillet $\mathbf{E}$. The role of allergic rhinitis in the development of otitis media with effusion. Healthmed 2013; 7(12): 3171-3178.

15. 15.Shishegar $M$ and Ashraf MJ. Comparison of histopathological characteristics and clinical behavior of acquired cholesteatoma. Marmara Medical Journal 2015; 28(2): 094.

16. Sharma K, Pannu M, Arora A and Sharma V. Preventive Audiology: Screening for Hearing Impairment in Children Having Recurrent URTI. Indian Journal of Otolaryngology Head Neck Surgery 2016; 68(2): 163-166.

17. Hurst DS. The role of allergy in otitis media with effusion. Otolaryngologic Clinics of North America 2011; 44(3): 637-654.

18. Chantzi FM, Kafetzis DA, Bairamis T, Avramidou C, Paleologou N, Grimani I, et al. IgE sensitization, respiratory allergy symptoms, and heritability independently increase the risk of otitis media with effusion. Allergy 2006; 61: 332-6.

19. Chonmaitree $T$, Trujillo R, Jennings $K$, AlvarezFernandez P, Patel JA, Loeffelholz MJ, et al. Acute Otitis Media and Other Complications of Viral Respiratory Infection. Pediatrics 2016; 137(4): e20153555-e20153555.

20. Costa SSD, Rosito LPS, and Cristina DC. Sensorineural hearing loss in patients with chronic otitis media. Eur Arch Otorhinolaryngol 2009; 266:221-224.

21. Peltola H, Laipio ML \& Siimes MA. Quantitative C-reactive Protein (CRP) Determined by an Immunoturbidimetric Method in Rapid Differential Diagnosis of Acute Bacterial and Viral Diseases of Children. Acta Paediatrica 1984; 73(2): 273-274.

22. Tejani NR, Chonmaitree T, Rassin DK, Howie VM, Owen MJ \& Goldman ASJP. Use of Creactive protein in differentiation between acute bacterial and viral otitis media. pediatrics 1995; 95(5): 664-669.

23. Nofal K \& Al Kwatly K. Serum interleukin-6 and C-reactive protein in bacterial otitis media patients in Damascus city. Journal of Chemical Pharmaceutical Research 2015; 7(7): 403-408.

24. Schwartz RH, Hayden GF, Rodriguez WJ, Sait T, Chhabra OM \& Golub J. Leukocyte counts in children with acute otitis media. Pediatric Emergency Care 1986; 2(1): 10-14.

25. Polachek A, Greenberg D, Lavi-Givon N, Broides A, Leiberman A, Dagan R, et al. Relationship Among Peripheral Leukocyte Counts, Etiologic Agents and Clinical Manifestations in Acute Otitis Media. The Pediatric Infectious Disease Journal2004; 23(5): 406-413.

26. Wintergerst ES, Maggini S, Hornig DH. Contribution of selected vitamins and trace elements 
to immune function. Ann Nutr Metab 2007; 51: 301 23.

27. Salah ET, Ahmed E, Elhussien M \& Salah T. The use of vital signs as predictors for serious bacterial infections in children with acute febrile illness in a pediatric emergency setting in Sudan. Sudanese journal of paediatrics 2014; 14(2): 35 .

28. Teele DW, Klein JO, Rosner BA. Epidemiology and natural history of otitis media in children. Ann Otol Rhinol Laryngol 1980; 89(3): 5-6.
29. Pukander J, Luotonen J, Sipila M, Timonen M and Karma P. Incidence of acute otitis media. Acta Otolaryngol 1982; 93: 447-453.

30. Matsuoka A. Inflammatory middle ear diseases in children: sex differences. Nippon Jibiinkoka Gakkai Kaiho 1994; 97: 436-9.

31. Ohta N, Ueki S, Hirokawa M, TomiokaMatsutani S, Kawano T, Miyasaka T, et al. Possible clinical implication of eosinophil extracellular traps in eosinophilic otitis media. Otorhinolaryngology-Head and Neck Surgery 2019; (4): 3-4. 


\section{المدخص العربي المني \\ تقييم العلاقة بين التهاب الأذن الوسطى وصريز الصدي المدر عند الأطفال

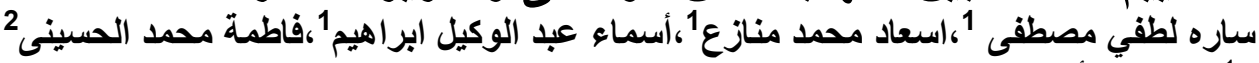

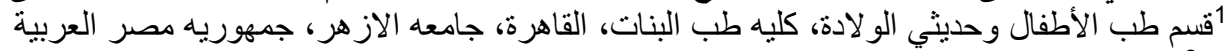

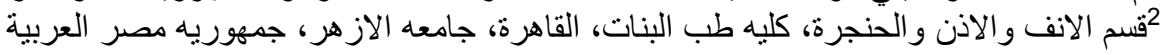

ملخص البحث

الخلفية: في الأطفال يعتبر صرير الصدر عرض مشهوره يحتاج الى استشارات طبيه وخدمات الرعاية في حالات

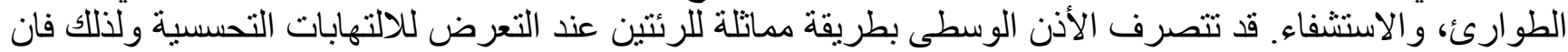

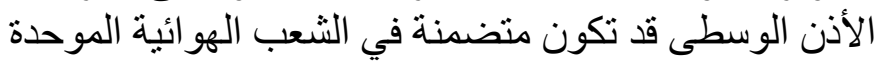

الههف: الكثف عن الارتباط بين صرير الصدر ووجود التهاب الأذن الوسطى في الأطفال الطرق: شملت هذه الدراسة 100 طفل يعانون من صرير الصدر، 54 ذكر 46 أنثى. خضعت جميع الحالات للأخذ

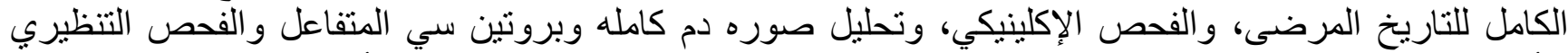
للأذن وقياس ضغط الطبلة، وقياس السمع، بالإضافة إلى استجابة جذع الدماغ السمعي في الأطفال غير المتعاونين

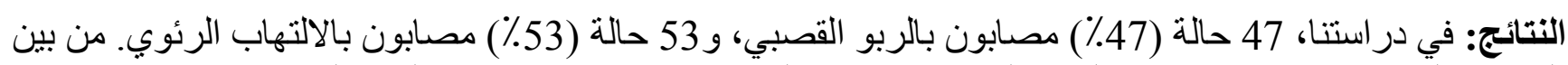

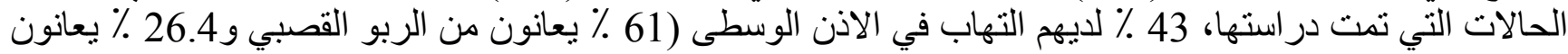

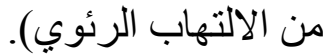

حالات التهاب الاذن الوسطى كانت 39 حالة (90.6\%) تعاني من من بين 43 حالة من فقدان السمع التوصيلي، في حين أن 4 حالات (9.3\%) كانت تعاني من فقدان السمع العصبي الحسي. فقر الدم لله علاقة

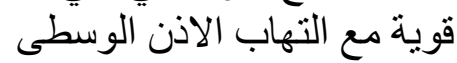
الأستتناجات: هنالك ارتباط بين صرير الصدر، مهما كان سبيه الربو القصبي أو الالتهاب الرئوي، وحدوث التهاب الاذن الوسطى. الكلمات المفتاحية: الأطفال، صرير الصدر، التهاب الأذن الوسطى، فقدان السمع التوصيلي. الأسم: ساره للطفي مصطفى، قسم طب الاطفال وحديثي الو لادة، كليه طب البنات، القاهرة، جامعه الازهر ، جمهوريه مصر العربية

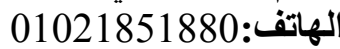
البريد الإكتروني: Saralotfymf@gmail.com 